\title{
Agricultural development is economic development: Kentucky State Parks local food purchasing case study
}

\author{
Robert R. Perry, University of Kentucky
}

Submitted 8 April 2011 / Accepted 2 May 2011 / Published online 21 July 2011

Citation: Perry, R. (2011). Agricultural development is economic development: Kentucky State Parks local food purchasing case study. Journal of Agriculture, Food Systems, and Community Development, 1(4), 3-13.

http://dx.doi.org/10.5304/jafscd.2011.014.010

Copyright (C) 2011 by New Leaf Associates, Inc.

\section{Introduction}

In April 2004 I was appointed director of food service for the Kentucky (KY) State Park system and charged with improving its 21 restaurant operations - qualitatively, physically, and financially. Kentucky's state park system is one of the largest in the nation, especially in its number of food service operations. The operations included 17 full-service resort park restaurants scattered widely across the state in primarily rural areas, as well as three state employee cafeterias located in Frankfort and the café at the KY Artisan Center in Berea.

Having been a chef for over 25 years and been brought up in a gardening family, it was the quality of the food that was most important to me.

Sourcing locally produced foods was just beginning to become prominent and is now the most signifi-

Robert R. Perry is project manager and chef for the Sustainable Agriculture \& Food Systems Working Group in the College of Agriculture at the University of Kentucky, Lexington, KY USA; +1-859-257-1692; Bob.Perry@uky.edu cant trend in the restaurant industry. I knew that procuring locally grown foods would result in not only better quality food and thus more sales at the park restaurants, but also help to improve the farm economy of Kentucky that was and still is in turmoil following the elimination of the tobacco program. With the KY State Park system's annual food purchases averaging around US $\$ 5,000,000$, buying directly from farmers within the state would be a huge boost to the state's economy in general and the farm economy in particular.

This is a personal account of my experience trying to localize a large and widely dispersed institutional food service operation. It began as does this paper with produce, especially tomatoes, and herein I explain how I was able to break through decades of bureaucracy to buy directly from Kentucky farmers. The sections on proteins include the benefits to the farmers of selling to the parks, as well as an examination of the volume of beef and pork used by the parks and the impact it could have had on Kentucky's economy. While there have been several new diary operations come into existence 
since, the trials and tribulations I went through in buying local dairy and eggs are still applicable today. The section on value-added foods highlights the prohibitive cost of local production and packaging for the restaurant industry. Local foods and on-farm dinners were a novelty in 2004, but our experiments with them extended the potential use of local foods, and especially value-added items.

I only held this position for two years, and in a very politically charged environment. ${ }^{1}$ The conclusion looks at the action taken when my tenure in this position ended and looks at the potential impact these programs could still have on farms and the economy in Kentucky and beyond. The lessons I learned are not limited to parks, but are applicable to all types of restaurants and food service operations, both public and private and including schools, hospitals, colleges and universities.

\section{Produce Purchasing}

The first project I undertook was to implement the purchase of locally grown produce for all 21 operations directly from the farmers at the back doors of all the operations. The Kentucky Department of Agriculture (KDA) had been trying to gain access to the park system for KY farmers for years without success, and I was quickly told by the outgoing park's long-time purchasing director that this would be impossible for a wide variety of reasons. Undaunted, I called the KDA and set up a meeting to discuss the possibilities.

\footnotetext{
${ }^{1}$ In 2006 Kentucky elected the first Republican governor in 36 years, which resulted in the first significant turnover of appointed and senior managemant positions in decades. To say that the existing systems, policies, and employees were mired in bureaucracy and dated would be a massive understatement.
}

I also contacted the two most prominent nongovernment advocacy groups in the state, Partners for Family Farms (PFF) and Community Farm Alliance (CFA). PFF administered the "Restaurant Rewards" program that provided rebates directly to restaurants that purchased certified Kentucky

Proud agricultural products. ${ }^{2}$ CFA is a well organized advocacy group that lobbies on behalf of farmers and seeks to expand markets and programs associated with sustainable and local farming. CFA is supported primarily by members' dues and foundation grants and has a wide network across the state. These two groups provided a wealth of connections, information, support, advice, and later, publicity for this project.

There were two major obstacles to overcome in the purchasing process: what price to offer and how to actually pay the farmers. Since food purchases for these operations are made with taxpayer dollars, certain statutes and regulations apply, primarily concerned with getting the best value for the taxpayers, i.e., price. Fortunately produce and seafood were exempt from any bid requirement or contract because of price and supply volatility.

Pricing for produce was established by constructing a weekly price for all seasonal produce based on an average price from several existing approved commercial vendors. In this way, the cost of the local produce would not exceed the price already being paid, and would fluctuate with the seasonality of the items. We made the price list available to the farmers near every KY State Parks operation. We expected these prices to be slightly below farmer's market prices, and substantially above wholesale or

\footnotetext{
${ }^{2}$ Each restaurant could receive up to US $\$ 1,000$ per month based on a $20 \%$ rebate.
} 
auction prices. Comparing the prices we calculated this way with both the reported auction and farmers' market prices by the New Crops Opportunity Center at the University of Kentucky bore this theory out. ${ }^{3}$

Payment to local farmers can be notoriously slow throughout the restaurant industry, and there was a concern that trying to get an invoice paid through the state's system would mirror this problem, or be worse. Paying in cash at the back door was not an option as none of the operations was allowed to keep a petty cash fund. This problem was solved with by developing a direct payment option. Farmers were required to register with the KDA's Kentucky Proud program and fill out a simple information sheet at the location they desired to sell to that included their business information and a bank account number where funds could be transferred. Payment was allowed to be authorized at each park, rather than requiring approval from the park's central office in Frankfort, as the average dollar transaction fell well below the small purchase authority of each operation. Produce was delivered directly to each operation, weighed, entered on that week's price sheet, and signed by both the farmer and the chef. The price sheet was then sent to the operation's business office for approval and submitted for payment. This was really little extra burden on existing purchasing procedures, especially for the large parks that employ a dedicated purchaser and stock clerk.

This produce program began in August 2004 and met with moderate success even though it began near the end of the growing season and none of the farmers had anticipated this additional market. Total purchases for the first year still exceeded US $\$ 6,000$ even in this short time frame.

\footnotetext{
${ }^{3}$ The New Crops Opportunity Center is now the Crop Diversification \& Biofuel Research \& Education Center and can be accessed at http://www.uky.edu/Ag/CDBREC/
}

An enormous amount of press coverage also resulted from the initial effort to purchase local produce. Many of the state's newspapers featured articles, including a lead editorial in the Lexington Herald Leader. The agricultural press coverage was extensive, including an interview for a statewide radio program. Regional and national magazines also picked up the story in both the popular and trade press. The two largest audiences came from an article in Organic Gardening and an interview on the NPR program "The Splendid Table."

Following the successful launch of this program, I began to participate in a series of meetings during the winter with farmers across the state and with staff from the KDA and the UK Cooperative Extension service to explain the program and answer questions about it. The response was enthusiastic, and several farmers made comments about the ease of getting into the program during the launch phase. One grower commented that he made as much profit selling bell peppers to a park restaurant as he had selling his entire crop to a co-op. Some farmers even brought seed catalogs to the meetings wanting to know specifically what varieties of produce the chefs would like.

As all local purchasing must be based necessarily on establishing relationships, many of these meetings were held at state park facilities and included the chef of the operation whenever possible. The chefs were also enthusiastic about the program and most reported great success starting it and the high quality produce they received. Total purchases for 2005 were approximately US $\$ 21,500$. While this was less than we had hoped for, this was the first full growing season for the program and Kentucky also experienced a major drought throughout most of the state that year.

\section{Beef}

With the initial success of the produce program and its promotion through the meetings held around the state, meat and dairy farmers began 
asking about selling directly to the park system as well. This brought on an entirely new set of hurdles to overcome, first and foremost the existing regulation that these items be bid on an "all state agencies" contract to try and get the lowest price for all state government-run operations, including schools, hospitals, justice facilities, and parks. The park's small purchase authority only allowed purchases from a single vendor of up to US $\$ 5,000$ outside of the contract for any commodity, an amount that would be quickly reached with meat and dairy purchases. The answer was to seek a regulatory change to exempt the park's meat and dairy purchases from this contract and treat them like produce and seafood.

Several meetings were held in spring and summer 2005 with representatives from the departments of Parks, Commerce, Agriculture, and Finance. It was determined that it was within the secretary of finance's authority to change the regulation governing meat and dairy purchases to include them in the exemption for produce and seafood. I was told by attorneys for the Finance Cabinet that we could not specify "Kentucky Grown" products, as that would be a violation of parts of the Interstate Commerce Act, but could specify "locally grown" in the regulation. ${ }^{4}$ Therefore, one of the questions asked was how to define "local purchasing" of meat and dairy. My answer was that products would be purchased directly from and delivered by the farmers themselves, and since many of the parks were located along the state's borders, this would not preclude purchases from nearby farms in neighboring states or any farmer willing to make direct deliveries. Having successfully satisfied the legalities of changing the regulation, the next step was to put it before the legislative committee that approves regulatory changes in this area. This regulation change was approved unanimously after the second reading by that committee and went into effect in October 2005. An unanticipated

\footnotetext{
4 The state of KY was acting as a "market participant" and therefore not in violation of the dormant Commerce Clause doctrine, as discussed at http://www.agdevjournal.com/ attachments/115 JAFSCD Laws on Locally Grown Food Corrected 10-10.pdf
}

aspect of this regulation was that it allowed the park system's operations to seek the best price for fresh meat and dairy products from all vendors, in the same manner that private-sector operations do rather than adhering to the all-state agencies contract with a single large nationwide food service company.

Around this time another meeting was held with several of the state's meat and dairy farmers who were interested in selling directly to the park operations. All these farmers were already retailing their own products in some manner and wanted to expand their operations. Most of the beef farmers faced the same problem: they could sell all the steaks they could cut at a premium, but had trouble selling the roasts and ground beef. It was then that I realized that the parks' usage of beef cuts would match perfectly with the cuts the farmers were having trouble selling, but in a slightly different and more beneficial form to the farmers.

The parks' restaurants had always featured a popular Sunday lunch buffet that included a roast beef carving. Originally this was a "Steamship" beef roast, which is an entire hindquarter of beef, roasted and carved bone-in. In recent years this cut had been changed to a boneless top round or inside round. While easier to handle, cook, and carve, it does not have the flavor of a joint of meat cooked on the bone and was definitely not as attractive at the end of a buffet line.

The benefits of using steamships for the parks were the magnificence of the presentation, the improved flavor of meat cooked on the bone, and the panache of using a locally raised product. For the farmers, this was a way to sell approximately one-third of the carcass weight of the animal without significant further processing and its associated costs, leaving only the steaks and ground beef. In additiona, parks could take most of the ground beef in the form of hamburger patties due to their volume of sales, which left the producer with only the most profitable steaks to sell. I was able to create a spreadsheet for each park that showed the poundage of each cut of beef used every month for 
an entire year. Using this spreadsheet, cattle farmers could have theoretically worked out a feed and slaughtering schedule almost to the day needed by the park restaurants. With a guaranteed market to dispose of two-thirds of a carcass, local cattlemen could have safely increased their throughput and built their businesses selling the most desired and profitable cuts directly. My hope was that as they began to create economies of scale, their finer cuts of beef would then become affordable for parks to serve as well, further promoting their products. Coincidentally, some of the parks are located in close geographic clusters and there were cattle farmers near each cluster who were interested in selling directly to their nearby parks, without any competition between them.

There were short-term and long-term economic benefits for doing this - besides offering an excellent product to the parks' guests. The shortterm benefit was in helping to build the local farmer's "brand" or name by serving their products to large numbers of guests who patronized the parks' restaurants and by using table tents and signage to make it known where the meat came from. A significant method of product promotion is to seek "marketing impressions" by getting the product or the name in front of the consumer. One of the best examples of this is in NASCAR racing sponsorship. The cars are so emblazoned with product names it is impossible not to see one no matter what camera shot is shown on television. You also see product placement in movies and television shows, and the companies pay enormous fees for this service. Placing the farms' names in front of the state parks' $1,800,000$ customers per year provided a lot of free marketing impressions to promote their products. It was hoped this would encourage customers to seek out the farms' products for their own use at home. Still, there is no better way to convince someone of the superior quality of locally produced, sustainable food than to put it in their mouth, and the volume of sales at the state park restaurants could have done just that.

The long-term goal was to build a brand for "KY Beef' in general that would help all cattle farmers by increasing the demand for their products locally, and hopefully foster further development in onfarm, pasture finishing and local processing of cattle and the job creation and economic benefits this would have fostered. As table 1 shows, it would have taken 782 head cattle just to provide the needed steamship roasts in 2005, more than all the cattle being finished and USDA-processed locally combined at that time.

For all this to work though, the ugly business of price had to be dealt with, especially since it was the public taxpayers' money. The parks' restaurants, however, operated on a retail business model, unlike the remainder of government food service operations, which operated on an institutional model where money was budgeted per person/per meal. The two beef farmers I worked with from the beginning were able to price their

\footnotetext{
${ }^{5}$ At an average of 60 pounds each, this equates to 782 cattle needed for just this cut.
} 
Table 2. KY State Parks Pork Usage, 2005 (all prices in US\$)

\begin{tabular}{lrrrrr}
\hline & & \multicolumn{1}{c}{ Cut } \\
& $\mathbf{5}$ oz Chops & \multicolumn{1}{c}{ Cutlets } & Country Ribs & Boneless Loins & Boston Butts \\
\hline Lbs./year & 9,866 & 4,706 & 15,031 & 23,282 & 19,945 \\
Price & $\$ 2.09$ & $\$ 2.03$ & $\$ 1.82$ & $\$ 1.72$ & $\$ 0.92$ \\
Totals & $\$ 20,619$ & $\$ 9,553$ & $\$ 27,356$ & $\$ 40,045$ & $\$ 18,349$ \\
& & & & & \\
& Spareribs & Pit Ham & Sausage & Bacon & \\
Price & 22,176 & 34,586 & 30,665 & 68,998 & \\
Totals & $\$ 1.54$ & $\$ 2.10$ & $\$ 1.38$ & $\$ 2.11$ & \\
\hline
\end{tabular}

Total \$ $\$ 410,606$

hamburger patties at a very nominal US $\$ 0.15$ increase per patty above the commodity patty that was on contract. The price difference was easily offset simply by increasing the menu price by the same amount or slightly more as any private-sector

restaurant would do. The price difference to switch back to using steamships from local farmers was approximately US $\$ 1.00$ per pound and the difference could have been addressed in the same way, to slightly raise the price of the Sunday buffet, perhaps even as nominally as US $\$ 0.30$ per person since one steamship of beef can service 200 customers on a buffet with multiple proteins. ${ }^{6}$

As the figures in table 1 show, if this program were fully implemented, it would have returned US\$345,327 annually (shaded cell) to local beef farmers and therefore the local economy, not including the increased business for small local meat processors. The increase in overall food cost would have been less than 1\% (US\$12M US\$102,858) which could have been more than offset by a modest increase in menu prices as discussed above. Systemwide, this would have represented an increased cost of US $\$ 0.06$ per customer, a small price to pay for real agricultural and economic development in a park system that required a US\$30,000,000 annual taxpayer subsidy.

What the above figures and discussion does not account for is the actual difference in quality with

${ }^{6}$ A steamship weighing $60 \mathrm{lbs} \mathrm{X}$ US $\$ 1.00$ per pound price increase $\div 200$ customers $=$ US $\$ 0.30$ per customer increase regard to price; it is not comparing apples to apples. The locally produced beef in this program was pasture finished, free of added antibiotics, steroids and hormones (ASH), and was "dry aged," all attributes that usually command much higher prices than commodity beef of any grade. High-end steak houses dry age individual cuts of beef to improve flavor and then charge accordingly. Local farmers and restaurants generally do not have this ability and can only dry age the entire carcass at the processor for a similar result. This means that even the hamburger patties are dry aged, something few other commercial or private operations offer.

\section{Pork}

While there were several sustainable cattle farmers across the state, sustainable pork farmers were nonexistent at the time. However, the quantity of pork purchased by the park system could have provided a large, stable market and served as a catalyst encouraging more farmers to go back into pork production, especially pastured and woodland production systems for heirloom breeds that command higher prices.

As table 2 indicates, the park restaurants went through an incredible amount of fresh pork in 2005 , totaling US $\$ 410,606$ at commodity prices, potentially an even larger economic impact than beef. When direct marketing pork it is usually the shoulders (Boston butts) that are the hardest to sell, much like roasts when direct marketing beef. This market would have easily overcome that problem as the park restaurants served a large quantity of barbecue made from the shoulders as well as the hams. In beef, where the grind is also hard to sell, ground pork seasoned as sausage was also high-volume item. Not represented in this ta- 
ble are the value-added products like country hams and city (deli) hams, of which the park restaurants also used a large quantity. These products could have provided income not only for the farmers raising the pigs, but also for the small local processors, especially those with the facilities and expertise to make the value-added products.

On a positive note, the market for pastured pork has exploded in Kentucky in the last couple of years, and there are numerous farms now producing several heirloom breeds on pasture. The state parks could still help these farmers immensely by instituting a program for purchasing local pork, although developing the model would be much more difficult than that for beef, as the commodity prices for pork are artificially low and the price differential would be much greater than that with local beef.

\section{Poultry}

The use of local, sustainably raised poultry was not explored during this time frame as there were no poultry processors in the state the working with smallscale farms. Kentucky now has three poultry processors working exclusively with small farms, the newest of which is capable of processing 2,500 birds per day, including air chilling and retail packaging. It is doubtful that state park restaurants could use locally raised poultry due to the higher cost of raising poultry sustainably on small-scale farms together with the higher processing cost.

\section{Dairy}

There were only two opportunities to add local dairy products to the park system - ice cream and cheese - and both were considered. One dairy farm in south central Kentucky had found success building a replica barn as a sandwich shop and ice cream parlor and making gourmet ice creams flavored with local fruits. They marketed the opera- tion as an agritourism venue by offering farm tours for school kids and regular folks. While they made ice cream on the premises, they had to sell their milk to a commercial processor and buy mixed commodity milk back to make the ice creams that might or might not have contained any of their own milk. We discussed their desire to install pasteurization equipment to cut out this middle step that would have made their ice creams more affordable and to process fluid milk.

They would only have been able to supply a few nearby parks with ice cream or milk because they did not have any type of distribution system in place, which would have increased the price further, and the major distributors were not interested in working with them. However, Western Kentucky University (WKU) in Bowling Green was also interested in purchasing fluid milk at that time, as they were trying to foster a Farm to College program. WKU would have been an excellent market for them, as they were only a few miles up the road with a large student population and several large dining venues with considerable volume during the school year. The nearby state parks could have completed their market year; the parks peak season is during the summer months when the dining operations at WKU are abridged.

Another dairy producer had begun to produce an incredible variety of high quality cow's milk cheeses in a plant built on their farm. Distribution was not a problem for them as they shipped regularly with FedEx and built the cost into their product. Also, they only sold the cheeses in blocks and did not have slicing equipment. The prices for their cheeses were also out of reach for day-to-day operations in the park restaurants, but we were able to bring in some diary products to the state park 
operations for special events as described in the section on KY Proud Dinners.

The diary making ice creams has since partnered with another nearby dairy that built an on-farm fluid milk processing plant. The ice-cream-making dairy delivers its raw milk to the other for processing and gets it back in bulk for ice cream processing and in retail fluid milk packaging, which they have in a regional grocery chain's dairy cases. The cow's milk cheese maker is still going strong and continues to develop new cheeses. Since that time there are now also several other cow cheese makers using milk from sustainable dairies, two goat cheese producers, and soon a sheep's milk cheese processor will start production.

\section{Eggs}

There were a number of farms offering pastured eggs across the state that easily could have sold their eggs to the state park operations, but price was the factor. When the word really started to get out that park restaurants were seeking local products, I had this email exchange with an egg producer (edited for privacy) that illustrates the situation.

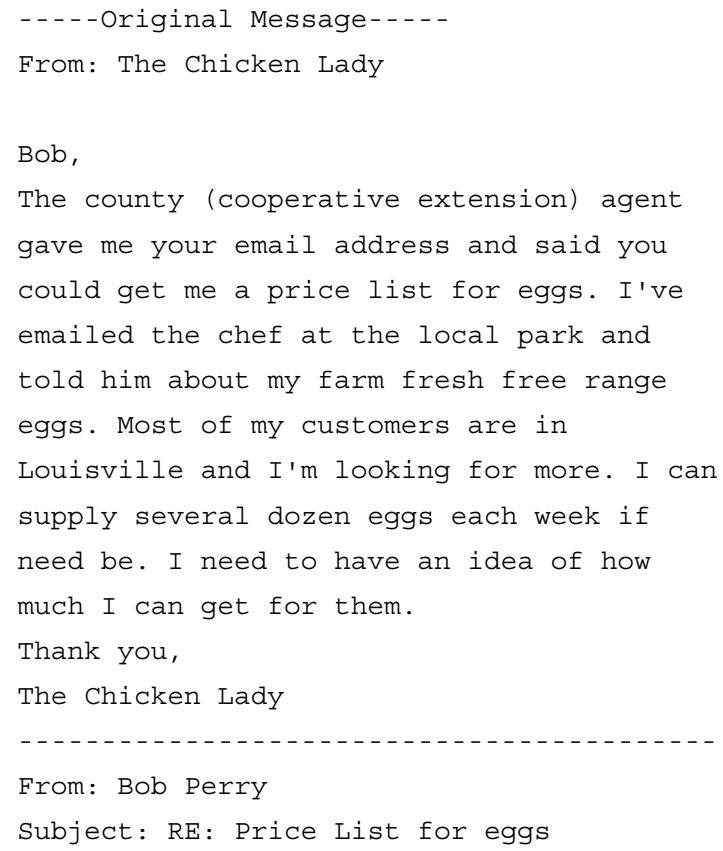

Below are recent prices we paid for fresh

eggs, a food service case is 12 dozen. The chef can tell you how many they use in a week.

$1 / 27 / 05--7.50$ per case----0.052 each

2/01/05 - - 10.50 per case---0.072 each

2/15/05 - 10.80 per case---0.075 each

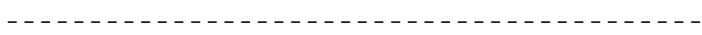

From: The Chicken Lady

Subject: RE: Price List for eggs

Bob, no offense but, save your time. We were hoping that quality had more value than that. As much as we would like to see Kentucky institutions support Kentucky raised produce, these prices would put all of us out of work. We can get a tax deduction for giving them to non-profits that give us more value than these prices.

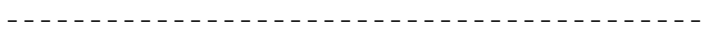

From: Bob Perry

That is one of the biggest problems I face in trying to bring $\mathrm{KY}$ products into the parks. I know you can sell at much greater prices to white tablecloth restaurants that can then upcharge their customers to cover the costs. Our customers in parks are not that sophisticated...yet, and are primarily families on vacation looking for value in dining, especially w/ several kids in tow. I know you can also sell to individuals who know and appreciate your product... and can afford it.

I hope that as we grow local agriculture the farmers can get big enough and have enough volume production to sell to all restaurants at wholesale prices that are acceptable, but not so big that they lose the localness of production. It is the middle ground that is the real challenge and key to all of this. Reaching the average restaurant that serves the average customer at a price everyone can be happy with. 
Don't give up hope, I have only started on this project for parks and we have a long way to go...Bob

In addition to my naïveté at the beginning of this initiative, this email exchange shows that trying to match the price between locally produced farm goods and commercially produced items is nearly impossible. The quality and wholesomeness of the products must be considered when determining the difference in price between commercially produced products and sustainably produced local products. Recent work in food value chains and case studies about ag of the middle ${ }^{7}$ show great promise in scaling up sustainable farm products without losing these qualities.

\section{Value-Added Products}

On-the-farm and community-kitchen production of value-added products such as jams, jellies, BBQ sauces, and salsa were more difficult but not impossible to bring into the parks food service operations. There was a US\$5,000 small purchase authority that allowed operations to buy food up to that amount from individual sellers without violating the model purchasing code. This came into play with most value-added products, as categories of these fell under the grocery contract awarded by a competitive bid process. These products are part of the "market basket" purveyors bid on, not separate commodities. It would have taken a regulatory change or exemption to facilitate large-scale usage of these type items in the park system, similar to the way local meat and dairy was exempted.

Cost again is a major factor with value-added products; it is hard for local producers to reach an economy of scale to come anywhere close to prices for commercial products. One problem for many products is package size, as it is cost prohibitive for the small farmers to put their products into the portion-control packaging many operations prefer to use. This could have been overcome by buying the product in bulk and then spooning it into portion-control food service containers in the operations as they did with ketchup and other

\footnotetext{
7 http://www.agofthemiddle.org/
}

condiments. Locally made BBQ sauce is a good product to illustrate this point.

I received a sample of a BBQ sauce made with locally produced honey that I thought was very good. The producers had won several contests with their sauce and they sought to have their local park restaurant purchase and use it. I asked that first they contact the KDA to certify their sauce as a "KY Proud" product to assure that it was indeed made with locally produced agricultural products. When this was done they called the park's chef and offered to sell their product in a gallon size, at US $\$ 24.00$ each. The chef called me and asked what to do; he had tested their sauce and liked it, but could not see where he could afford to use it in the quantity he needed. Commercial BBQ sauce was US $\$ 4.00$ a gallon and there was no way to increase the price of the BBQ menu items to cover that much of an increase in sauce price.

I did not get to resolve this situation before leaving the parks department, but feel certain I could have worked out a compromise. Inasmuch as valueadded products would benefit from the marketing impressions on the menus as described above in the discussion of beef, the state parks also operate many gift shops. If the producer were willing to work with a price that would allow for use in the restaurant, they would also be able to sell at a better price for retail resale in the gift shops. Shelf stable value-added agricultural products are big sellers in gift shops, and the parks have millions of shoppers every year who would represent a large market for these products. The ability of shoppers to taste before purchasing and the panache of a local product on the menu would be a big plus for both the producers and the restaurants.

\section{KY Proud Dinners}

While all-local-food and on-farm dinners are common now, in 2004 they certainly were not. These dinners grew initially out of a request for a catered function utilizing as many KY Proud food products as possible. Who sent the original request escapes me now as there were so many that followed. Whether it was a reception featuring an array of finger foods, a buffet meal for a large 
number, or a sit-down multicourse meal, the idea was to incorporate as many local products as possible to showcase Kentucky agriculture's diversification since the demise of tobacco as the state's number-one crop.

While it was difficult to incorporate more expensive food items into existing menus of ongoing restaurants, it is much easier to control food costs with catered functions. We knew in advance the exact number of people to prepare for, and the cost per person could be calculated based on the total cost of the food. This allowed the bill to reflect the normal profit margin as it would have been with commercial food products. I found that the cost to the customer was only slightly higher, but the quality of the food more than made up for the additional cost, besides the prestige for the host by offering a local menu.

These dinners were very successful but required some creativity for produce during the off season. This was accomplished through the creative use of value-added products to add a flavor of KY Proud to commercial foodstuffs when locally grown or raised items could not be found. These functions also allowed the use of specialty cheeses and ice creams as mentioned above, since price was not as much of a factor and the extra effort required for delivery could be worked out in advance. Sometimes delivery was taken care of by personnel traveling around the state in their normal duties at no additional cost.

What was a growing trend at the time is now de rigueur for top chefs and restaurants. Chefs Collaborative, Slow Food and other organizations have really pushed the issue in recent years, and as demand has grown from restaurants and the gen- eral public, farmers have responded by further diversifying their operations to provide more of both quality and quantity.

\section{Conclusion: Agricultural Development Is Economic Development}

Upon my untimely departure from this position in early 2006, Community Farm Alliance was able to shepherd the passage of a bill to establish a preference for locally grown products that would require all state agencies (including the park restaurants) to continue to pursue the projects I had started. ${ }^{8}$ It was a valiant effort but the language in the bill fell short, and since it was enacted little has been done to promote local purchasing. In fact, succeeding management reversed every single initiative started during my tenure and put the restaurants back on a cookie-cutter, low-end chain restaurant format where every park cooks the exact same menu from an approved purchasing list.

Kentucky's Economic Development Cabinet states that its purpose is "to support and promote economic development within the state, primarily by attracting new industries to the state, assisting in the development of existing industries, and assisting communities in preparing for economic development opportunities." Like Dorothy in her ruby slippers, economic development folks at the federal, state, and local level need to realize that the power to significantly affect the economy is right under their feet in the form of their farmers' boots. The monthly Department of Labor report on the number of jobs is always defined as "nonfarm" jobs, as if self-employed farmers and their hired help do not contribute anything worth calculating in the overall national economy. However these

\footnotetext{
${ }^{8}$ http://www.lrc.ky.gov/Statrev/ACTS2006/0244.pdf

${ }^{9}$ http://www.thinkkentucky.com/KYEDC/WhoWeAre.aspx
} 
on-farm jobs could greatly affect the economy, especially in rural areas where jobs are the scarcest. For every farmer or farm employee who can return to a farm full-time or even part-time, it opens up their previous nonfarm job to someone else. Indirect effects of these onfarm jobs would be even more rural jobs in the support businesses and the economic multiplier effect of the direct farm income and wages that are spent locally. This job re-creation does not take require tax breaks and credits or massive inputs of taxpayer money for infrastructure improvements to support a new factory. It only takes a stable market for the food that the farms can produce.

If the KY State Park restaurant operations only purchased beef, pork and produce as outlined here, the initial annual economic impact directly to KY farmers would be well over US $\$ 1,000,000$ without any additional tax dollars being spent. If other city, county, and state facilities followed suit, it would create a multimillion dollar, stable market for locally grown products that would truly foster the diversification and sustainability of Kentucky's family farms.

Kentucky is fortunate to still have thousands of small family farms as a result of over a century of dependence on tobacco and its price supports. With properly scaled processing facilities and access to markets, most of these farms could successfully diversify and stay small family farms. Perhaps the most important task of all who support sustainable agriculture is to educate the public about the issues involved and encourage them to demand local food wherever they shop and eat. 